\title{
Effects of Soil-surface Morphology on Emergence and Sur- vival of Seedlings in Big Sagebrush Communities
}

\author{
RICHARD E. ECKERT, JR., FREDERICK F. PETERSON, MICHAEL S. MEURISSE, AND JENNIFER L. STEPHENS
}

\begin{abstract}
Various kinds of soil-surface microsites occur on loess-mantled Aridisols in central and northern Nevada. This study evaluates the potential of trampled and untrampled microsites to infuence natural revegetation and either secondary succession or retrogression. Microsites present on different soll surfaces included the litter-and moss-covered Type I surface that occurs under the shrub canopy; the trench-like cracks and pinnacled polygons of the Type II surface that occur adjacent to the Type I surface; and the narrow cracks and smooth polygons with crusted, vesicular structure of the Type III surface that occurs in the interspaces between shrubs. Emergence and survival of Wyoming big sagebrush generally were greatest on the Type I and III surfaces, in the untrampled crack microsite of the Type III surface, and on the heavily trampled polygon microsite of the Type III surface. Emergence and survival of perennial grasses generally were greatest on the untrampled Type I surface, in the untrampled trench microsite of the Type II surface, and on moderately trampled trench and pinnacle microsites of the Type II surface. Emergence of annual and perennial forbs generally was greatest on untrampled trench and crack microsites of the Type II and III soil surfaces. Heavy trampling of trench and crack microsites reduced the emergence of perennial grasses, and both moderate and heavy trampling reduced the emergence of annual and perennial forbs. The potential for secondary succession would appear to be greatest where Types I and II surfaces and associated microsites predominate on a site and when trampling is moderate or absent. The potential for retrogression would appear to be greatest where the Type III surface and associated microsites predominate and when trampling is heavy.
\end{abstract}

Cracks, protrusions, and flat spots on soil surfaces create a varied microrelief on loess-mantled Aridisols in Wyoming big sagebrush [Artemisia tridentata wyomingensis Beetle] and basin big sagebrush [A. tridentata tridentata Nutt.] communities of cen-

Authors are range scientist, USDA-ARS, 920 Valley Rd., Reno, Nev. 89512; soil scientist, Dep. of Plant Science, Univ. of Nevada, Reno 89557; and former graduate students, Dept. of Range, Wildlife, and Forestry, Univ. of Nevada, Reno 89512. Meurisse is currently area range conservationist, USDA, SCS, Area Office, 401

Houston, Manhattan, Kans. 66502.

This research is the result of cooperative investigations of the USDA-ARS and the Nevada Agr. Exp. Sta. Research was supported in part by the USDI-BLM.

Manuscript accepted 27 January 1986. tral and northern Nevada, southeastern Oregon, southern Idaho, and western Utah. This microrelief occurs on distinctive soilsurface morphological types that are found with considerable regularity on characteristic microtopographic positions (Eckert et al. 1977) (Fig. 1). The widely contrasting environmental conditions for seed germination and establishment of annual plants in microsites created by various soil-surface microrelief were shown by Harper et al. (1965) and Evans and Young (1972). Young et al. (1969) found that the number of favorable microsites, or "safe sites," on a soil surface determines the maximum possible population density of downy brome [Bromus tectorum L.]. Evans et al. (1970) and Evans and Young (1970) quantified temperature and soil moisture conditions in "safe sites" created by plant litter and by mechanical furrowing and drilling.

We postulate that some soil-surface microsites act as "safe sites" for seed germination, seedling emergence, seedling survival, and plant establishment. The number of microsites and the effects of cattle trampling on them could influence natural revegetation of perennial species reproducing by seed, as well as yearly establishment of annual species. In the Intermountain area for example, Hugie and Passey (1964) and Schlatterer (1968) found that seedlings of perennial grasses and forbs emerged and became established almost exclusively in cracks between polygons of certain soil-surface types.

Objectives of this study were to: (1) determine whether natural plant populations are related to the kinds of microsites present on various soil-surface types, (2) evaluate the influence of intensity of trampling by cattle on seedling emergence from various microsites, and (3) investigate emergence and survival of seedlings in relation to microsite and simulated trampling.

\section{Description of Soil-surface Microsites}

The surface soils studied have 2 general kinds of microsites: tops of polygons and cracks between polygons. The polygons actually are the tops of very coarse prisms that are the primary structural units of the A horizon. The soil-surface morphological types present on the sites studied are defined by the diameter of these polygons; by the flatness, convexity, or pinnacled nature of their tops, by the width and shape of cracks between them; and by their internal structure (Eckert et al. 1977). The Type I soil surface has 

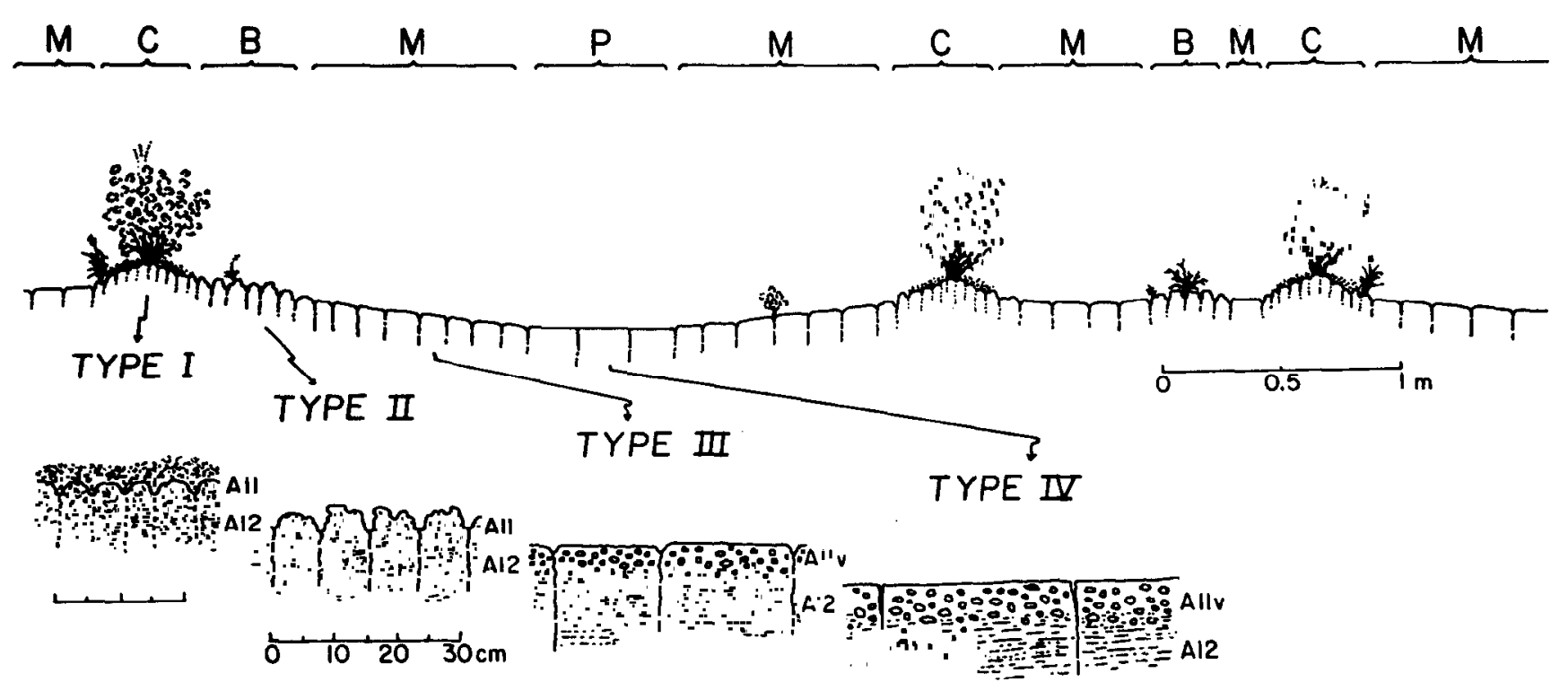

Fig. 1. Schematic cross-sectional diagram of the microtopographic positions and associated surface-soil morphological types on gently sloping, shallowly loess-mantled xerollic Orthids and Argids of the Humboldt Loess Belt. Microtopographic positions are: $C=$ coppice, $B=$ coppice bench, $M=$ intercoppice microplain, $P=$ playette. Vertical scale is somewhat exaggerated. Type I is litter covered. Circles indicate vesicle in crust ( $A$ l $v$ ).

convex-topped polygons about 5 to $10 \mathrm{~cm}$ in diameter that are separated by wide cracks (trenches) about $2 \mathrm{~cm}$ wide and 1 to $2 \mathrm{~cm}$ deep. Trenches are filled with litter and the entire surface is covered with litter, lichens, or moss [ Tortula ruralis (Hedw.) Gaertn. Meyer and Scherb] where protected from livestock trampling. Polygons are noncrusted, are only very slightly hard, and have a weak to moderate very fine subangular blocky structure. The Type II soil surface has polygons about 7 to $15 \mathrm{~cm}$ in diameter that are convextopped, or more commonly are frostheaved into irregularlyshaped pinnacles about 1 to $3 \mathrm{~cm}$ high by 2 to $3 \mathrm{~cm}$ in diameter. Polygons are separated by cracks (trenches) about $2 \mathrm{~cm}$ wide and 1 to $2 \mathrm{~cm}$ deep. This surface commonly is stabilized by cryptogams where protected from livestock trampling (Anderson et al. 1982). Polygons are only very slightly hard and massive or very weakly platy internally. The Type III soil surface has flat-topped polygons about 13 to $26 \mathrm{~cm}$ in diameter separated by narrow cracks that are about $1 \mathrm{~cm}$ wide and $1 \mathrm{~cm}$ deep. Polygons have a 1 to $4 \mathrm{~cm}$ thick, durable, vesicular crust. A Type IV surface has also been described but was not included in the present study because of its limited extent.

Livestock trampling may alter depression and surface microsites. A Type I surface is not likely to be trampled because it is protected by shrub cover. Trampling a Type II surface could crush the pinnacles, fill the trenches, and effectively cover any seed present. Since soil of this surface type doesn't form a durable crust, restriction of seedling emergence should be minimal. Trampling a Type III surface could mix seed and soil and fill the cracks. Since soil of this surface type slakes when saturated and dries to form a durable, vesicular crust, seedling emergence could be severely ressricted if the soil surface dries before seedlings emerge (Wood et al. 1978).

\section{Description of Study Sites and Methods}

\section{Natural Plant Populations}

A study of the influence of soil-surface microsites on natural plant populations was made on 12 sites in northcentral Nevada in spring 1978. Soils are all Aridisols and soil Family identification and site characteristics have been described by Eckert et al. (1986). Potential vegetation on all sites is Wyoming big sagebrush and Thurber needlegrass [Stipa thurberiana Piper]. All sites have been grazed by cattle and trampled for many years. Estimated annual precipitation for each site is 200 to $250 \mathrm{~mm}$. Data from 5 climatological stations in northcentral Nevada indicated about normal precipitation $(165 \mathrm{~mm})$ for the period October 1977 through March 1978. April 1978 was a particularly wet month with average precipitation of $47 \mathrm{~mm}$ or $318 \%$ of normal for these stations. This precipitation fell during 3 stormy periods of 2 to 6 days duration. May and June 1978 were very dry with precipitation of $18 \mathrm{~mm}$ or $32 \%$ of normal, however, most of this limited pecipitation fell in late May and in early June. These precipitation periods probably resulted in at least average seedling emergence in the spring and survival of these seedlings until time of sampling.

In June, $60,0.09-\mathrm{m}^{2}(30 \times 30 \mathrm{~cm})$ plots were randomly placed on the Type II surface and another 60 on the Type III surface in a homogeneous stand of vegetation representing the potential plant community on each site. The surface type and microsite sampled in each plot were required to meet the criteria for that kind of surface microtopography as defined by Eckert et al. (1977). Within each plot, seedlings and young plants on pinnacle or in trench microsites of the Type II surface and on polygon or in crack microsites of the Type III surface were counted. The numbers of plants on the 2 kinds of microsites were added to give the total plant density for each plot representing a particular soil-surface type. A young plant was defined as one small enough so that the microsite of emergence could be recognized. Shrubs and perennial grasses can be several years old and still meet this criterion. Differences in densities of the 3 most abundant species - big sagebrush, Sandberg bluegrass [Poa sandbergii Vasey], and the annual forb microsteris [Microsteris gracilis (Hook.) Greene] -and of all forbs and all species over all sites in relation to soil-surface type and microsite were determined by analysis of variance and Duncan's multiple range test. For less abundant species, the Chi-square test of independence ( $\mathrm{Li} \mathrm{1957)}$ was used to compare plant densities among surface types and microsites on individual sites.

\section{Trampling Intensity Efrects}

The influence of intensity of trampling by cattle on seedling density in various soil-surface microsites was studied on 2 sites north of Elko, Nev., in spring 1977 and 1978. Both sites are representative of the basin big sagebrush-bluebunch wheatgrass [Agropyron spicatum (Pursh) Scribn. and Smith] habitat type described by Hironaka et al. (1983) in southern Idaho. Perennial 
forbs constant to both sites are desert phlox [Phlox austromontana Cov.], wild onion [Allium spp. L.], tapertip hawksbeard [Crepis acuminata Nutt.], and biscuitroot [Lomatium spp. Raf.]. Common annual forbs are little flowered collinsia [Collinsia parviflora Lindl.], microsteris, groundsmoke [Gayophytum ramosissimum T. \& G.], Richardson's tansymustard [Descurainia Richardsonii (Sweet) O. Schultz], cryptantha [Cryptantha gracilis Osterh.], and gillia [Gillia transmontana (Mason \& A.D. Grant) A.D. \& V. Grant].

Site $I$ is on an alluvial fan remnant with a $2 \%$ NE slope and an elevation of $1,875 \mathrm{~m}$. The soil is a fine, montmorillonitic, mesic Durixerollic Haplargid. Vegetation is essentially a "closed community." Characteristics of this community include vegetation composed of mature big sagebrush and large plants of increaser species such as Great Basin wildrye [Elymus cinereus Scribn. and Merr.], squirreltail [Sitanion hystrix (Nutt.) J.G. Sm.] and Sandberg bluegrass. Few, if any, young perennial grass plants are present and the soil surface is stable. The site had been moderately grazed and trampled for many years. Moderate trampling was defined as some cattle hoof prints over the entire site, few cattle trails with disturbed and pulverized soil surface, cryptogam cover evident, and soil-surface types and microsites readily visible after grazing. An untrampled control was provided by an exclosure that had excluded cattle for 1 year.

Site 2 is on an alluvial fan remnant with $2 \%$ E slope and an elevation of $1,798 \mathrm{~m}$. Soil is a fine, montmorillonitic, mesic Xerollic Haplargid. Vegetation is a "very open community." Characteristics of this community include vegetation composed of mixed-age big sagebrush plants, sparse cover of increaser grasses, few perennial forbs, many annual forbs, and a large amount of bare ground. Grazing and trampling had been heavy for many years due to the presence of a water trough. Heavy trampling was defined as the area completely covered by hoof marks, many cattle trails, most of the soil surface pulverized into dust, cryptogam cover missing, and soil-surface types and microsites difficult to recognize after grazing. The untrampled control was in an adjacent highway right-ofway that had been fenced for 11 years.

Drought conditions in 1976-77 (150 mm precipitation or about $50 \%$ of normal at Site 1) resulted in very few seedlings at either site. Therefore, the relation between trampling and seedling emergence on soil-surface types and microsites could not be evaluated. Only results from spring 1978 are included in this paper. Measured precipitation of $254 \mathrm{~mm}$ on Site 1 from October 1977 through June 1978 was about $85 \%$ of the estimated long-term average. March and April precipitation was $56 \mathrm{~mm}$ or $240 \%$ of the long-term average. Based on daily precipitation records from a climatological station $32 \mathrm{~km}$ distant, 3 periods of precipitation in both March and April 1978 ranged from 3 to 5 days in length with from 5 to $30 \mathrm{~mm}$ of moisture in each period. May and June precipitation was $43 \mathrm{~mm}$ or about $20 \%$ of the long-term average; however, most of this limited precipitation fell at the end of May and in early June. These precipitation periods probably resulted in at least average seedling emergence in the spring and survival of the seedlings until time of sampling. Precipitation data were not collected at Site 2; however, since it is located only $16 \mathrm{~km}$ from Site 1 and in a similar topographic setting, amounts and distribution of precipitation should be similar to those at Site 1.

Both sites were grazed and trampled during the summer and fall of the year prior to sampling. In June, $100,0.09-\mathrm{m}^{2}(30 \times 30 \mathrm{~cm})$ plots were placed randomly on both trampled and untrampled Type II surface and Type III surfaces prior to cattle grazing. The seedlings on pinnacle and in trench microsites of the Type II surface and on polygon or in crack microsites of the Type III surface were counted for each plot. The number of plants on the 2 kinds of microsites were added to give total seedling density for each plot that represented a particular soil-surface type and trampling condition. Although data were collected from $0.09-\mathrm{m}^{2}$ plots, results are presented on 9- $\mathrm{m}^{2}$ basis to allow the use of whole numbers. The Chi-square test of independence was used to evaluate differences in seedling densities.

\section{Seeding and Simulated Trampling}

Emergence and survival of seedlings of native and introduced grasses were determined from seed sown on different microsites and covered by simulated trampling, or left untrampled. This study was conducted at 5 sites in 1976, 1977, and 1978. Sites and associated soils are: Coils Creek (Xerollic Durargid), Paradise Valley (Xerollic Nadurargid), Jiggs (Xerollic Duragrid), Panther Canyon (Xerollic Durorthid), and Dinner Station (Durixerollic Haplargid). All soils have mesic soil temperature regimes and are in fine-loamy soil families. The first 4 sites represent the Wyoming big sagebrush/Thurber needlegrass habitat type. The Dinner Station site represents the basin big sagebrush/bluebunch wheatgrass habitat type. Seed of 6 species was sown: Wyoming big sagebrush, Sandberg bluegrass, Thurber needlegrass, squirreltail, Nordan crested wheatgrass [Agropyron desertorum Schult.], and downy brome. In 1976, seed of each species was placed $1 \mathrm{~cm}$ apart on pinnacles, polygons, and in trenches or cracks on $225-\mathrm{cm}^{2}(15 \times 15$ $\mathrm{cm})$ plots. Seeding rate in 1977 and 1978 was 100 seeds per plot or each seed about $1.5 \mathrm{~cm}$ apart on polygons and in trenches and cracks. Pinnacles were not seeded after the first year because seeds apparently rolled or were washed from the pinnacles into the trenches. Location of each kind of microsite was charted prior to seeding in 1976 and 1977 at Coils Creek and Paradise Valley and compared to the location of microsites in 1977 and 1978. Trampling was simulated by pounding the soil surface with a nailstudded mallet after seeding until the soil surface was powdered to a depth of 2 to $3 \mathrm{~cm}$ as after heavy cattle use. Trampled and untrampled treatments were imposed on the Type I and II surfaces, and on polygons and in cracks of the Type III surface. All trampling treatments were not applied to all plots in some years. Each treatment combination was replicated 10 times. Seedling emergence was determined in the spring or spring and summer in each of 3 years, and after 2 years in 1 study to determine second-year survival. Density of natural sagebrush and downy brome seedlings on the Type I surface at 2 sites was great enough to confound determination of seedling density resulting from planted seed. On

Table 1. Mean density of seedlings and young plants on each microsite of Type II and III soil surfaces in June 1978 at 12 locations.

\begin{tabular}{|c|c|c|c|c|c|c|}
\hline $\begin{array}{l}\text { Soil-surface } \\
\text { type }\end{array}$ & Microsite & $\begin{array}{c}\text { All } \\
\text { species }\end{array}$ & $\begin{array}{c}\text { All } \\
\text { forbs }\end{array}$ & $\begin{array}{c}\text { Big } \\
\text { sagebrush }\end{array}$ & $\begin{array}{l}\text { Sandberg } \\
\text { bluegrass }\end{array}$ & Microsteris \\
\hline $\begin{array}{l}\text { II } \\
\text { III }\end{array}$ & $\begin{array}{l}\text { Pinnacle } \\
\text { Trench } \\
\text { Combined } \\
\text { Polygon } \\
\text { Crack } \\
\text { Combined }\end{array}$ & $\begin{array}{c}4.9 \mathrm{~b}^{1} \\
13.6 \mathrm{a} \\
18.5 \mathrm{y}^{2} \\
5.0 \mathrm{~b} \\
6.7 \mathrm{a} \\
11.7 \mathrm{z}\end{array}$ & $\begin{array}{c}3.7 \mathrm{~b} \\
10.3 \mathrm{a} \\
14.0 \mathrm{y} \\
2.7 \mathrm{~b} \\
4.0 \mathrm{a} \\
6.7 \mathrm{z}\end{array}$ & $\begin{array}{c}\text { No. } / 0.09 \mathrm{~m}^{2} \\
0.7 \mathrm{a} \\
0.7 \mathrm{a} \\
1.4 \mathrm{z} \\
1.8 \mathrm{a} \\
1.2 \mathrm{~b} \\
3.0 \mathrm{y}\end{array}$ & $\begin{array}{l}0.3 \mathrm{~b} \\
0.4 \mathrm{a} \\
0.7 \mathrm{y} \\
0.2 \mathrm{~b} \\
0.3 \mathrm{a} \\
0.5 \mathrm{y}\end{array}$ & $\begin{array}{l}2.7 \mathrm{~b} \\
3.8 \mathrm{a} \\
6.5 \mathrm{y} \\
2.0 \mathrm{a} \\
2.2 \mathrm{a} \\
4.2 \mathrm{z}\end{array}$ \\
\hline
\end{tabular}

iSpecies or species group means for each microsite within a soil-surface type followed by different letters (a or b) are significantly different ( $P \leq 0.05$ ) as determined by Duncan's multiple range test.

2Species or species group for each soil-surface type followed by different letters (y or $z)$ are significantly different $(P \leq 0.05)$ as determined by Duncan's multilple range test. 
these sites, counts of natural seedlings on adjacent unseeded plots were used to correct counts on seeded plots. Emergence and survival percentages were based on the number of live seeds planted as determined by germination tests. Differences in seedling densities were determined by analysis of variance, Duncan's multiple range test and Scheffe's test (Scheffe 1959).

The $\mathbf{0 . 0 5}$ level of probability was used to identify significantly different means in the 3 studies.

\section{Results and Discussion}

\section{Natural Plant Populations}

Average densities of seedlings and young plants for all species, all forbs, and for microsteris on 12 sites were significantly greater on the Type II surface than on the Type III surface, in trenches than on pinnacles of the Type II surface, and in cracks than on polygons of the Type III surface (Table 1). Sandberg bluegrass followed the same trend except that plant densities were similar on the Type II and III surfaces. Big sagebrush was the exception with significantly more plants on the Type III surface than on the Type II surface, similar densities in trenches and on pinnacles of the Type II surface, and more plants on polygons than in cracks of the Type III surface.

Of the less common species, only little-flowered collinsia on 4 sites had significantly higher plant densities on pinnacles of the Type II surface $\left(2.3\right.$ plants $\left./ 0.09 \mathrm{~m}^{2}\right)$ than on polygons of the Type III surface $\left(0.8\right.$ plant $\left./ 0.09 / \mathrm{m}^{2}\right)$. Density of downy brome plants was similar on pinnacles and polygons at 2 locations, but density was greater on polygons than on pinnacles at 2 sites. Plant densities of Thurber needlegrass were similar on pinnacles and polygons but significantly more plants were found in trenches of the Type II surface than in cracks of the Type III surface and in trenches and cracks than on pinnacles and polygons. For example, average plant density was $0.1,0.1,0.6$, and $1.1 / 0.09 \mathrm{~m}^{2}$ on polygons and pinnacles and in cracks and trenches, respectively. For desert phlox, plant densities in trenches and cracks $\left(0.5\right.$ and $\left.0.6 / 0.09 \mathrm{~m}^{2}\right)$ were similar and were significantly greater than densities on pinnacles and polygons $\left(<0.1\right.$ and $\left.0.2 / 0.09 \mathrm{~m}^{2}\right)$.

Most of these 12 sites are in early-to mid-seral range condition and most of the herbaceous vegetation grows on the Type II surface. Small-seeded species, such as a collinsia, appear to find an adequate safe site on the pinnacle microsite. Larger seed of annual and perennial grasses, perennial forbs, and microsteris probably fall in trenches of the Type II surface and may be covered with the friable soil on this surface type by trampling. The location of Type II surface near shrubs may also provide a protected microclimate and enhanced soil moisture due to shading and snow accumulation. Propagules disseminated by wind, such as those of squirrel- tail, composite forbs, and composite shrubs tend to blow across the soil surface. Seed may lodge in trenches of the Type II soil where soil is friable. Seed may also lodge in the narrow cracks of the Type III surface and have poor seed-soil contact, or cracks may fill with soil due to trampling. Seed may also remain on the polygon surface or be mixed into the soil by hoof action. If a durable crust forms after wetting and drying cycles, emergence in cracks and on the polygon surface could be restricted (Wood et al. 1978).

Although many seedlings may die after sampling, emergence of certin species appeared to be favored by certain kinds of microsites. The presence of some young plants in the sample suggests that these microsites also favor establishment.

\section{Trampling Intensity Effects \\ Location of Big Sagebrush Seedlings}

In the closed community represented by Site I, significantly more seedlings emerged on the untrampled $\left(117 / 9 \mathrm{~m}^{2}\right)$ than on the trampled $\left(96 / 9 \mathrm{~m}^{2}\right)$ area. In the untrampled area, significantly more seedlings were present on the Type 11 I surface than on the Type II surface ( 85 vs. $32 / 9 \mathrm{~m}^{2}$, respectively). On both surfaces, however, significantly more seedlings emerged in the depression trench and crack microsites than on the surface pinnacle and polygon microsites (Table 2). This response is important since depression microsites make up a much smaller part of each surface type than do surface microsites. With trampling, more sagebrush seedlings were also present on the Type III than on Type II surface (65 vs. $31 / 9 \mathrm{~m}^{2}$, respectively). On the Type II surface, seedling density was similar in trenches and on pinnacles; however, on the Type III surface, significantly more seedlings emerged on polygons than in cracks (Table 2). A possible explanation for the difference in seedling emergence between untrampled and trampled microsites on the Type III surface is that the small seeds of sagebrush fall either on polygons or in cracks. On untrampled surfaces, the cracks provide a more favorable microclimate for germination and emergence than do the polygon surfaces. Trampling, however, may fill the cracks, perhaps to a depth that restricts the light required for germination of sagebrush seed (Weldon et al. 1959) or to a depth from which seedlings cannot emerge. Moderate trampling of polygon surfaces could increase emergence by placing seed in contact with mineral soil (McIlvanie 1942, Beetle 1960). Also, since March and April precipitation was well above normal, reformed crust of the Type III polygon surface would be moist and soft following storm periods. Under these conditions seedling emergence is not restricted (Wood et al. 1978).

An opposite response by sagebrush seedlings was measured in the open community at Site 2 . Many more seedlings emerged in the heavily trampled $\left(7,234 / 9 \mathrm{~m}^{2}\right)$ than at the untrampled $\left(4,814 / 9 \mathrm{~m}^{2}\right)$ area. This much greater seedling density than found in the closed

Table 2. Mean denaity of big sagebrush and perennial buncherass seedlings in trench and on pinancle microutes of the Type Il surface and in crack and on polyzon microsites of the Type III surface in June 1978 at 2 locations. Both sites had been trampled by cattle or protected from trampling before sampling.

\begin{tabular}{|c|c|c|c|c|c|c|c|c|c|}
\hline & \multicolumn{2}{|c|}{ Type II } & \multicolumn{2}{|c|}{ Type III } & & \multicolumn{2}{|c|}{ Type II } & \multicolumn{2}{|c|}{ Type III } \\
\hline & Trench & Pinnacle & Crack & Polygon & & Trench & Pinnacle & Crack & $\overline{\text { Polygon }}$ \\
\hline $\begin{array}{l}\text { Site 1: Closed community } \\
\text { Big sagebrush } \\
\text { Sandberg bluegrass } \\
\text { Squirreltail }\end{array}$ & $\begin{array}{l}25 \mathrm{a}^{1} \\
35 \mathrm{a}^{*} \\
52 \mathrm{a}^{*}\end{array}$ & $\begin{array}{l}1-\mathrm{yr} \mathrm{p} \\
7 * 2 \\
2^{*} \\
2^{*}\end{array}$ & $\begin{array}{l}\text { ction } \\
56 \mathrm{a}^{*} \\
17 \mathrm{a}^{*} \\
12 \mathrm{a}^{*}\end{array}$ & $\begin{array}{r}29^{*} \\
2^{*} \\
4^{*}\end{array}$ & No. $/ 9 \mathrm{~m}^{2}$ & $\begin{array}{l}15 \\
90 a \\
85 a\end{array}$ & $\begin{array}{c}\text { Moderat } \\
16 \\
24 \\
26\end{array}$ & $\begin{array}{c}\text { mpling } \\
4 a \\
57 \\
38 a\end{array}$ & $\begin{array}{c}61 \\
131 \mathrm{a} \\
28\end{array}$ \\
\hline $\begin{array}{l}\text { Site 2: Open community } \\
\text { Big sagebrush } \\
\text { Sandberg bluegrass } \\
\text { Squirreltail }\end{array}$ & $\begin{array}{l}479 * \\
59 a^{*} \\
83 a^{*}\end{array}$ & $\begin{array}{c}11-y r \\
2521 a^{*} \\
6 \\
9\end{array}$ & $\begin{array}{c}\text { ction } \\
341 \\
18 \mathrm{a} \\
13 \mathrm{a}\end{array}$ & $\begin{array}{c}1473 a^{4} \\
4 \\
3\end{array}$ & & $\begin{array}{l}339 \\
25 a \\
33 a\end{array}$ & $\begin{array}{c}\text { Heavy } \\
3677 \mathrm{a} \\
6 \\
17\end{array}$ & $\begin{array}{c}\text { upling } \\
356 \\
11 \\
15 a\end{array}$ & $\begin{array}{c}2862 a \\
8 \\
7\end{array}$ \\
\hline
\end{tabular}

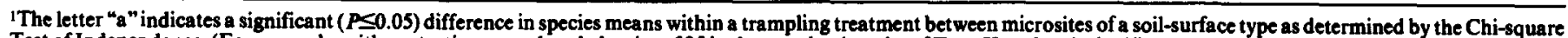

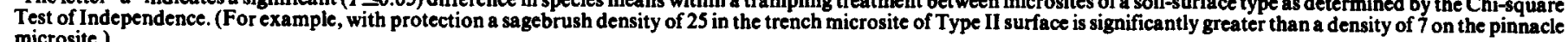
microsite.)

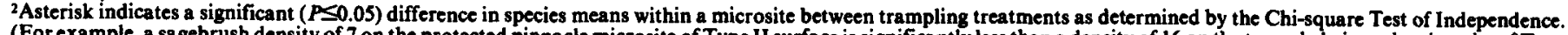

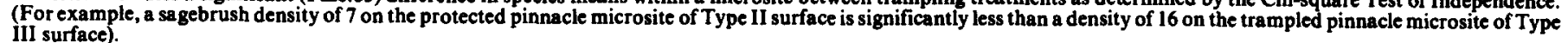


community at Site 1 may be due to less competition and higher sagebrush seed production on Site 2 . In the untrampled area, significantly more seedlings emerged on the Type II surface $\left(3,000 / 9 \mathrm{~m}^{2}\right)$ than on the Type III surface $\left(1,814 / 9 \mathrm{~m}^{2}\right)$. Seedling densities on trampled Type II and III surfaces were similar $(4,016$ vs. $3,218 / 9 \mathrm{~m}^{2}$, respectively), although the trend was for more seedlings on the Type II surface. On both trampled and untrampled Type II and Type III surfaces, significantly more seedlings emerged on pinnacle and polygon microsites than in trenches and cracks; however, the highest densities were found on the trampled surface microsites (Table 2). This response suggest that heavy trampling actually planted those seeds lying on the soil surface so that conditions for germination and emergence were improved. Significantly lower seedling densities in heavily trampled depression microsites suggest that seeds in trenches and cracks were covered too deep to emerge.

\section{Location of Perennial Grass Seedlings}

At Site I, significantly more perennial grass seedlings emerged on the moderately trampled area. Density of Sandberg bluegrass seedlings was $302 / 9 \mathrm{~m}^{2}$ on the trampled area and $56 / 9 \mathrm{~m}^{2}$ on the untrampled area. For squirreltail, seedling densities were 177 and $70 / 9 \mathrm{~m}^{2}$, respectively, on trampled and untrampled areas. Seedling densities of both species were also significantly greater on the trampled than on untrampled microsites (Table 2). The moderate trampling at this site appeared to enhance seedling emergence, probably by planting seed lying uncovered in trenches and cracks and on the surface of pinnacles and polygons. With 1 exception, seedling densities of both grasses were significantly greater in trenches and cracks than on pinnacles and polygons regardless of the trampling treatment; more bluegrass seedlings emerged on trampled polygons than on trampled cracks. Like sagebrush, the small seed of bluegrass that lodged in cracks may be planted too deep when cracks are filled with soil due to trampling.

At Site 2, significantly fewer perennial grass seedlings emerged on the heavily trampled area. Seedling density of Sandberg bluegrass was $50 / 9 \mathrm{~m}^{2}$ on the trampled area and $87 / 9 \mathrm{~m}^{2}$ on the untrampled area. For squirreltail, seedling density was $72 / 9 \mathrm{~m}^{2}$ on trampled surfaces and $108 / 9 \mathrm{~m}^{2}$ on untrampled surfaces. Heavy trampling apparently destroyed many microsites favorable to the species. In addition, less perennial grass seed may have been pro-

Table 3. Mean density of perennial and annual forb seedlings in trench and on pinnacle microsites of the Type II surface and in crack and on polyson mierodtes of the Type III surface in June 1978 at Site 1 . This site had been trampled by cattle or protected from trampling before sampling.

\begin{tabular}{|c|c|c|c|c|c|c|c|c|}
\hline & \multicolumn{2}{|c|}{ Type II } & \multicolumn{2}{|c|}{ Type III } & \multicolumn{2}{|c|}{ Type II } & \multicolumn{2}{|c|}{ Type III } \\
\hline & Trench & $\overline{\text { Pinnacle }}$ & Crack & Polygon & Trench & Pinnacle & Crack & Polygon \\
\hline $\begin{array}{l}\text { Perennial forbs } \\
\text { Desert phlox } \\
\text { Wild onion } \\
\text { Hawksbeard } \\
\text { Biscuitroot }\end{array}$ & $\begin{array}{l}89 a^{1 * 2} \\
59 a^{*} \\
38 a \\
47 a\end{array}$ & $\begin{array}{l}1-y r ~ P \\
7 \\
14 \\
2 \\
6\end{array}$ & $\begin{array}{l}\text { tion } \\
120 \mathrm{a}^{*} \\
51^{*} \\
56 \mathrm{a}^{*} \\
52 \mathrm{a}^{*}\end{array}$ & $\begin{array}{r}5 \\
49 \\
12 \\
14\end{array}$ & $\begin{array}{r}342 a \\
12 \\
21 a \\
26 a\end{array}$ & $\begin{array}{c}\text { Modera } \\
13 \\
18 \\
7 \\
7\end{array}$ & $\begin{array}{c}\text { mpling } \\
196 a \\
15 \\
13 a \\
25 a\end{array}$ & $\begin{array}{r}24 \\
20 \\
7 \\
9\end{array}$ \\
\hline $\begin{array}{l}\text { Annual forbs } \\
\text { Little-flowered } \\
\text { collinsia } \\
\text { Microsteris }\end{array}$ & $\begin{array}{l}584 a^{*} \\
182 a^{*}\end{array}$ & $\begin{array}{l}80^{*} \\
46^{*}\end{array}$ & $\begin{array}{l}245 \mathrm{a}^{*} \\
200 \mathrm{a}\end{array}$ & $\begin{array}{r}98^{*} \\
159^{*}\end{array}$ & $\begin{array}{l}342 a \\
103 a\end{array}$ & $\begin{array}{r}139 \\
28\end{array}$ & $\begin{array}{r}163 \\
61\end{array}$ & $\begin{array}{r}164 \\
69\end{array}$ \\
\hline
\end{tabular}

The letter $\mathrm{ua}_{\mathrm{a}}$ indicates a significant $(P \leq 0.05)$ difference in species means within a trampling treatment between microsites of a soil-surface type as determined by the Chi-square Test of Independence.

${ }^{2}$ Asterisk indicates a significant $(P \leq 0.05)$ difference in species means within a microsite between trampling treatments as determined by the Chi-square Test of Independence.

Table 4. Percent seedling emergence in early June 1978, seedling survival in late July 1978, and second-year survival in late July 1979 at 2 sites in northern Nevada expressed as a percent of the number of live seeds planted in late summer 1977."

\begin{tabular}{|c|c|c|c|c|c|c|c|c|c|c|c|c|c|}
\hline \multirow[b]{2}{*}{ Site } & \multirow[b]{2}{*}{ Treatments $^{3}$} & \multicolumn{3}{|c|}{ Artrw (78) } & \multirow{2}{*}{$\frac{\text { Stth (56) }}{\text { June } 78}$} & \multicolumn{3}{|c|}{$\begin{array}{l}\text { Species }^{2} \\
\text { Sihy (90) }\end{array}$} & \multicolumn{3}{|c|}{ Posa (51) } & \multirow{2}{*}{$\frac{\text { Agde (89) }}{\text { June } 78}$} & \multirow{2}{*}{$\frac{\text { Brte (92) }}{\text { June } 78}$} \\
\hline & & June 78 & July 78 & July 79 & & June 78 & July 78 & July 79 & June 78 & July 78 & July 79 & & \\
\hline $\begin{array}{l}\text { Coils } \\
\text { Creek }\end{array}$ & $\begin{array}{l}\text { IT } \\
\text { IIT } \\
\text { IIICT } \\
\text { IIICUT } \\
\text { IIIPT }\end{array}$ & $\begin{array}{l}9.0 \mathrm{a}-\mathrm{c} \\
3.9 \mathrm{~d} \\
2.6 \mathrm{~d} \\
3.2 \mathrm{~d} \\
3.0 \mathrm{~d}\end{array}$ & $\begin{array}{l}3.7 \mathrm{~b} \\
1.7 \mathrm{e} \\
1.2 \mathrm{f} \\
0.3 \mathrm{~h} \\
1.7 \mathrm{e}\end{array}$ & $\begin{array}{l}0.4 \mathrm{de} \\
0.4 \mathrm{de} \\
0.0 \mathrm{e} \\
0.0 \mathrm{e} \\
0.0 \mathrm{e}\end{array}$ & $\begin{array}{l}2.6 \\
5.5 \\
4.2 \\
1.5 \\
4.4\end{array}$ & $\begin{array}{c}7.4 \mathrm{~b}-\mathrm{d} \\
8.8 \mathrm{a}-\mathrm{c} \\
9.0 \mathrm{a}-\mathrm{c} \\
2.9 \mathrm{~d} \\
11.4 \mathrm{ab}\end{array}$ & $\begin{array}{l}4.0 \mathrm{a} \\
3.2 \mathrm{c} \\
3.0 \mathrm{~d} \\
0.7 \mathrm{~g} \\
3.7 \mathrm{~b}\end{array}$ & $\begin{array}{l}1.7 \mathrm{c}-\mathrm{e} \\
1.2 \mathrm{c}-\mathrm{e} \\
0.0 \mathrm{e} \\
0.0 \mathrm{e} \\
1.3 \mathrm{c}-\mathrm{e}\end{array}$ & $\begin{array}{c}6.7 \mathrm{~b}-\mathrm{d} \\
11.3 \mathrm{ab} \\
13.0 \mathrm{a} \\
9.1 \mathrm{a}-\mathrm{c} \\
11.1 \mathrm{ab}\end{array}$ & $\begin{array}{l}1.2 \mathrm{f} \\
0.2 \mathrm{i} \\
0.2 \mathrm{i} \\
0.0 \mathrm{j} \\
0.2 \mathrm{i}\end{array}$ & $\begin{array}{l}2.4 \mathrm{bc} \\
4.4 \mathrm{a} \\
4.0 \mathrm{ab} \\
2.8 \mathrm{a}-\mathrm{c} \\
2.2 \mathrm{~b}-\mathrm{d}\end{array}$ & $\begin{array}{l}1.6 \\
1.6 \\
0.8 \\
1.6 \\
0.6\end{array}$ & $\begin{array}{l}5.8 \mathrm{~cd} \\
7.5 \mathrm{~b}-\mathrm{d} \\
7.3 \mathrm{~b}-\mathrm{d} \\
3.0 \mathrm{~d} \\
8.7 \mathrm{a}-\mathrm{c}\end{array}$ \\
\hline $\begin{array}{r}\text { Paradise } \\
\text { Valley }\end{array}$ & \begin{tabular}{l}
\multicolumn{1}{c}{ IIT } \\
IIICT \\
IIICUT \\
IIIPT
\end{tabular} & $\begin{array}{c}23.8 \mathrm{c}-\mathrm{e} \\
7.5 \mathrm{i}-\mathrm{l} \\
2.4 \mathrm{k}-1 \\
3.2 \mathrm{j}-1 \\
7.7 \mathrm{i}-1\end{array}$ & $\begin{array}{l}7.6 \mathrm{~b} \\
3.4 \mathrm{e} \\
6.4 \mathrm{c} \\
2.5 \mathrm{f} \\
2.3 \mathrm{~g}\end{array}$ & $\begin{array}{l}1.4 \mathrm{~b}-\mathrm{e} \\
1.4 \mathrm{~b}-\mathrm{e} \\
0.9 \mathrm{c}-\mathrm{e} \\
0.4 \mathrm{de} \\
0.5 \mathrm{de}\end{array}$ & $\begin{array}{l}6.9 \\
5.4 \\
4.4 \\
- \\
-\end{array}$ & $\begin{array}{l}35.1 \mathrm{a} \\
28.6 \mathrm{a}-\mathrm{d} \\
24.8 \mathrm{~b}-\mathrm{e} \\
10.7 \mathrm{~g}-\mathrm{k} \\
13.1 \mathrm{f}-\mathrm{i}\end{array}$ & $\begin{array}{c}12.1 \mathrm{a} \\
4.3 \mathrm{~d} \\
0.7 \mathrm{i} \\
0.4 \mathrm{j} \\
0.8 \mathrm{~h}\end{array}$ & $\begin{array}{l}3.9 \mathrm{ab} \\
0.9 \mathrm{c-e} \\
0.0 \mathrm{e} \\
0.8 \mathrm{e} \\
0.0 \mathrm{e}\end{array}$ & $\begin{array}{l}9.1 \mathrm{~h}-\mathrm{k} \\
17.0 \mathrm{e}-\mathrm{h} \\
18.6 \mathrm{e}-\mathrm{g} \\
11.4 \mathrm{~g}-\mathrm{j} \\
14.0 \mathrm{f}-\mathrm{i}\end{array}$ & $\begin{array}{l}0.1 \mathrm{~m} \\
0.0 \mathrm{n} \\
0.0 \mathrm{n} \\
0.0 \mathrm{n} \\
0.0 \mathrm{n}\end{array}$ & $\begin{array}{l}4.8 \mathrm{a} \\
3.6 \mathrm{a}-\mathrm{c} \\
2.9 \mathrm{a}-\mathrm{d} \\
4.2 \mathrm{a} \\
4.4 \mathrm{a}\end{array}$ & $\begin{array}{c}12.3 \\
16.0 \\
15.6 \\
- \\
-\end{array}$ & $\begin{array}{l}32.6 \mathrm{ab} \\
19.0 \mathrm{e}-\mathrm{g} \\
30.1 \mathrm{a}-\mathrm{c} \\
28.9 \mathrm{a}-\mathrm{d} \\
21.2 \mathrm{~d}-\mathrm{f}\end{array}$ \\
\hline
\end{tabular}

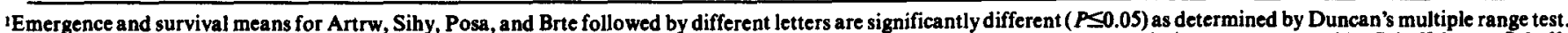

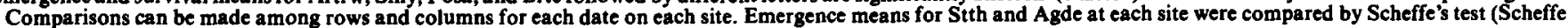
1959). Means without letters indicate no significant differences.

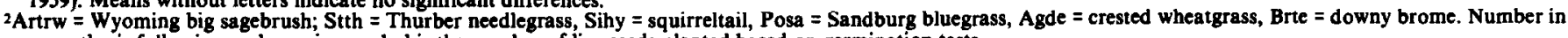
parenthesis following each species symbol is the number of live seeds planted based on germination tests.

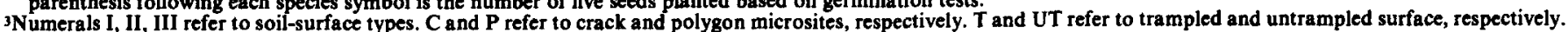


duced in the heavily grazed area than in the protected area. With 1 exception, significantly more grass seedlings emerged from trenches and cracks than from pinnacles and polygons regardless of the trampling treatment; with trampling, density of bluegrass seedlings was similar in crack and on polygon microsites of the Type III surface (Table 2).

\section{Location of Forb Seedlings}

An example of the response of perennial and annual forbs to kind of microsites on trampled and untrampled surfaces is given for Site 1 (Table 3). Without trampling, or with moderate trampling, significantly more seedlings of most forb species emerged in trenches and cracks than on pinnacles and polygons and significantly more seedlings emerged from untrampled depression microsites than from moderately and heavily trampled trenches and cracks. Phlox was an exception. Perennial forbs showed no differential responses on trampled or untrampled surface microsites. On surface microsites, annual forbs had a differential response that varied with species (Table 3 ). At Site 2 , seedling densities of all perennial forbs in both depression and surface microsites were always significantly lower in heavily trampled than in untrampled microsites. The response of annual forbs at Site 2 showed no consistent response to trampling or microsite, although the trend was for more seedlings of cryptantha, gillia, and tansymustard on the untrampled Type II soil surface and more seedlings of groundsmoke on the heavily trampled Type III surface.

\section{Seedling and Simulated Trampling}

Surface and depression microsites of the Type II and III surfaces tend to reform in the same position the year after simulated trampling. Therefore, the emergence and survival of a specific plant can be related to a specific microsite. In general, less than $1 \%$ of the live seed planted by simulated trampling treatments on 3 soil surfaces at 2 sites in late summer 1976 produced seedlings in spring 1977. This poor seedling emergence was attributed to the low winterspring precipitation. At Coils Creek, the measured precipitation of $81 \mathrm{~mm}$ from October 1976 through June 1977 was estimated to be $30 \%$ of the long-term average. Measured precipitation at Paadise Valley from October 1976 through June 1977 was $123 \mathrm{~mm}$, or $75 \%$ of the long-term average. May and June precipitation totaled 112 $\mathrm{mm}$ or $250 \%$ of normal at Paradise Valley. Precipitation in May fell on 13 days from the 3 rd to the 27 th in periods of 2 to 10 days and with amounts of from 2 to $16 \mathrm{~mm}$. Precipitation in June fell on 5 days from the 8 th to the 20 th in periods of 2 to 3 days and with amounts of from 10 to $57 \mathrm{~mm}$. Following these events, $32 \%$ of the seed of crested wheatgrass and squirreltail produced seedlings on the trampled Type I surface only, but emergence of Thurber needlegrass was still less than $1 \%$. No seedlings of any species, however, survived the summer.

Seedling emergence in June 1978, survival in July 1978, and 2-year survival in July 1979 from the 1977 planting were determined on 5 sites. Results from Coils Creek and Paradise Valley (Table 4) typify responses obtained on other sites. Overall emergence was highest at Paradise Valley and Panther Canyon where $\mathbf{3 0 \%}$ of the long-term average. Measured precipitation at Paradise Valley from October 1976 through June 1977 was $123 \mathrm{~mm}$, or $75 \%$ measured precipitation from October 1977 through June 1978 was 251 and $294 \mathrm{~mm}$, respectively. These amounts are estimated to be about 125 and $120 \%$ of average for these 2 sites, respectively. Lower emergence occurred at Coils Creek, Dinner Station, and Jiggs where measured precipitation from October through June of 202,254 , and $192 \mathrm{~mm}$, respectively, was estimated to be about 80 , 85 , and $85 \%$ of average for these sites. Emergence of crested wheatgrass and Thurber needlegrass on various soil surfaces and trampling treatments at these sites varied from 0.6 to $14.4 \%$, but a significant difference among species occurred only at the Jiggs site where Thurber needlegrass emergence was $13.3 \%$ when seed was placed in cracks of the Type III surface and covered by simulated trampling. More sagebrush seedlings emerged on the trampled Type I surface than on any other trampled surface. Emergence of squirreltail seedlings was variable but good emergence occurred with most treatment combinations, particularly on Paradise Valley (Table 4). Differences among treatment means for Sandberg bluegrass were not always significant, however, the general trend was toward fewer seedlings on the trampled Type I surface. Small bluegrass seeds may have been planted too deep by simulated trampling on his friable surface. Good emergence of downy brome occurred at Paradise Valley and Panther Canyon, however, even on sites with poor emergence, seedlings occurred on most soil surfaces and trampling treatments. This response, particularly on the Type III surface, suggests a reason why cheatgrass is such a successful invader species.

Survival of seedlings of most species into late July 1978 was greatest on trampled Type I surface under shrubs (Table 4). Shade provided by shrub cover and a friable soil with litter cover probably created a more favorable microsite for survival than that present in the interspaces between shrubs.

Measured precipitation from October 1978 through July 1979, during the second year after seeding, varied from 168 to $283 \mathrm{~mm}$ at the 5 sites. These amounts were about $80 \%$ and $95 \%$ of average for the Paradise Valley and Coils Creek sites, respectively, and about $75 \%$ of average for the other sites. Considerable seedling mortality occurred between June 1978 and July 1979 (Table 4). Survival of sagebrush plants ranged from 0 to $1.4 \%$ based on the number of live seeds planted with no significant differences among soilsurface sites or simulated trampling treatments. A conversion from survival percentage to density of surviving plants showed that up to 12, 2-year old plants $/ \mathrm{m}^{2}$ were present-a large number of surviving plants from a single seeding. Survival of squirreltail plants ranged from 0 to $3.9 \%$ (0 to 39 plants $/ \mathrm{m}^{2}$ ) with the most plants on the trampled Type I surface at Paradise Valley (Table 4). In many degraded big sagebrush stands, squirreltail plants occur close to, or under shrubs. However, 39 plants $/ \mathrm{m}^{2}$ is an unrealistic number for a site to support, and many of these plants will die before equilibrium with site potential is reached. More Sandberg bluegrass plants were counted in July 1979 than in July 1978 (Table 4) because distinguishing between live and dead plants was difficult in 1978 . Since bluegrass goes dormant very early in the summer, many plants must have been classified as dead when actually they were dormant. When counts were repeated in 1979, these plants were classified as live. After 2 years, survival of bluegrass was significantly greater than that for sagebrush or squirreltail on most soil surfaces and microsites at most locations. All these plants cannot establish; many will die and others will coalesce to form the typical large clumps of bluegrass found under shrubs and in interspaces between shrubs.

The 1978 planting was evaluated in early June and late July 1979. An untrampled treatment on Type 1 and II surfaces in 1978 permitted a comparison with trampled surfaces. Both emergence and first-year survival were significantly higher, or tended to be higher, on the trampled Type I and II surfaces than on respective untrampled surfaces. At Coils Creek, for example, respective emergence on trampled vs. untrampled Type II surface was: $\mathbf{3 6 . 3}$ vs. $15.1 \%$ for sagebrush, 5.9 vs. $0.0 \%$ for Thurber needlegrass, 8.7 vs $1.1 \%$ for squirreltail, 17.3 vs. $1.8 \%$ for crested wheatgrass, and 32.0 vs. $7.1 \%$ for cheatgrass. Respective survival on the trampled and untrampled Type II surface was 1.5 vs. $0.9 \%$ for sagebrush, 2.9 vs. $0.0 \%$ for Thurber needlegrass, 3.7 vs. $0.1 \%$ for squirreltail, and 7.7 vs. $0.4 \%$ for crested wheatgrass. All differences were significant except for sagebrush survival.

\section{Summary and Conclusions}

Species responded differently in trampled and untrampled soilsurface microsites. These differences most likely are related to seed size; shape, size, and exposure of each microsite; physiological requirements of each species for seed germination, seedling emergence and survival, and plant establishment; and the effective environment present on each microsite each year. Seedlings sampled in the study indicate only a potential for natural revegeta- 
tion. Plants 2-years old or older indicate that certain microsites do provide an environment for establishment of desirable and unde sirable species, although recruitment of new plants may be episodic. The frequency of establishment of plants of different species determines the speed of secondary succession or of retrogression. If soil-surface conditions mainly favor the establishment of increaser and invader species, then ecological range condition will improve very slowly or be static due to competition from the undesirables. If soil-surface conditions mainly favor the establishment of desirable species, the potential for improved range condition increases, provided a seed source is present.

Results of this study suggest 2 working hypotheses: (1) Emergence and establishment of desirable species are favored by the Type I and II soil surfaces. Therefore, the probability of natural revegetation by desirable species and thus secondary succession is greater on sites with a large areal proportion of these surface types. Conversely, secondary succession may be very slow, may not occur, or retrogression may occur on sites with a large areal proportion of Type III surface because undesirable species can successfully emerge and establish on this surface. (2) Trampling can alter the suitability of soil-surface microsites for species emergence. Moderate trampling appears to favor emergence of perennial grasses on all microsites, is not detrimental to emergence of perennial forbs on surface microsites, but is detrimental to emergence of perennial forbs in depression microsites. Heavy trampling appears to favor emergence of sagebrush and some weedy annual forbs especially on the pinnacle and polygon microsites that constitutes a large proportion of the soil surface. Heavy trampling is detrimental to emergence of perennial grasses and perennial forbs in all microsites.

\section{Literature Cited}

Anderson, D.C., K.T. Harper, and R.C. Holmgren. 1982. Factors influencing development of cryptogamic soil crust in Utah deserts. J. Range Manage. 35:180-185.

Beetle, A.A. 1960. A study of sagebrush the section Tridentatae of Artemisia. Wyoming Agr. Exp. Sta. Bull. 368.
Eckert, R.E., Jr., F.F. Peterson, M.K. Wood, and W.H. Blackburn. 1977. Properties, occurrence, and management of soils with vesicular surface horizons. Final Report, Contract 5250-CT5-(N) between the USDI, Bureau of Land Management and the Nevada Agr. Exp. Sta.

Eckert, R.E., Jr., F.F. Peterson, and J.T. Belton. (1986). Relation between ecological range condition and proportion of soil-surface types. J. Range Manage. 39:416-420.

Evans, R.A., H.R. Holbo, R.E., Eckert Jr., and J.A. Young. 1970. Functional environment of downy brome communities in relation to weed control and revegetation. Weed Sci. 18:154-162.

Evans, R.A., and J.A. Youns. 1970. Plant litter and establishment of alien annual weed species in rangeland communities. Weed Sci. 18:697-702.

Evans, R.A., and J.A. Youns. 1972. Microsite requirements for establishment of annual rangeland weeds. Weed Sci. 20:350-356.

Harper, J.L., J.T. Williame, and G.R. Sanger. 1965. The behavior of seed in soil. I. The heterogeneity of soil surfaces and its role in determining the establishment of plants. J. Ecol. 53:273-286.

Hironaka, M., M.A. Fosber, and A.H. Winward. 1983. Sagebrush-grass habitat types in southern Idaho. College of Forestry, Wildlife, and Range Science. Univ. of Idaho, Moscow. Bull. 35.

Hugie, V.K, and H.B. Passey. 1964. Soil surface patterns of some semiarid soils in northern Utah, southern Idaho, and northeastern Nevada. Soil Science Soc. of America Proc. 28:786-792.

Li, J.C.R. 1957. Introduction to statistical inference. Edwards Brothers, Inc. Ann Arbor.

MeIlvanie, S.K. 1942. Grass seedling establishment, and productivity overgrazed and protected range soils. Ecol. 23:228-231.

Scheffe, H. 1959. The analysis of variance. John Wiley and Sons, Inc. N.Y.

Schlatterer, E.F. 1968. Establishment and survival of three native grasses under natural and artificial conditions. M.S. Thesis. Univ. of Idaho, Moscow.

Weldon, L.W., D.W. Bohmont, and H.P. Alley. 1959. The interrelation of three environmental factors affecting germination of sagebrush seed. $J$. Range Manage. 12:236-238.

Wood, M.K., W.H. Blackbum, R.E. Eckert, Jr., and F.F. Peterson. 1978. Interrelations of the physical properties of coppice dune and vesicular dune interspace soil with grass seedling emergence. J. Range Manage. 31:189-192.

Young, J.A., R.A. Evans, and R.E. Eckert, Jr. 1969. Population dynamics of downy brome. Weed Sci. 17:20-26.

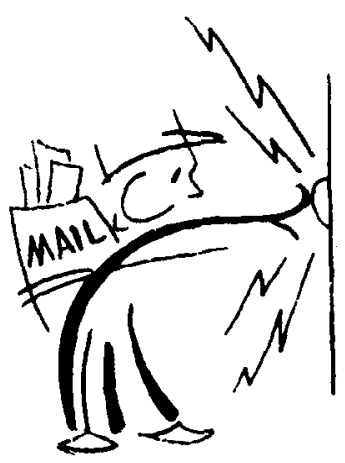

MOVING? Please try to give us four weeks notice. Send your present address label and this form to Society for Range Management 2760 W. 5th Ave. Denver, Colo. 80204

Name ...................

New Address $\ldots \ldots \ldots \ldots \ldots \ldots \ldots$

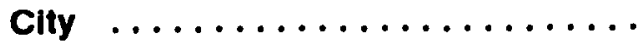

State

Zip $\ldots \ldots \ldots$ 